\title{
CONTENTS
}

I. GREAT THINKERS. (I) SOCRATES: R. HACKForth, M.A. - $\quad 259$

II. TWO PHILOSOPHERS OF THE OXFORD MOVEMENT: ClEMENT

C. J. WeBB, D.Litt. • • • • • • • • • • 273

III. CROCE'S THEORY OF ECONOMIC ACTION: Professor W. G. DE BURGH • • • • • • • • • • • • • • • 285

IV. THE SENSE OF THE HORIZON: C. Delisle Burns, D.Lit. . · 30I

V. A PLURAlistic vieW of history: Adrian Coates, M.A. . 318

VI. DISCUSSION: PROFESSOR WHITEHEAD'S ADVENTURES OF IDEAS: SYDNEY E. HOOPER, M.A. . . . . . . . 326

VII. PHILOSOPHICAL SURVEY:

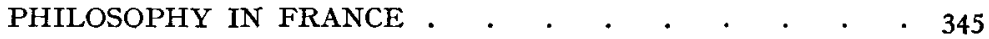

PHILOSOPHY IN GERMANY . • . . . . . . 349

VIII. NEW BOOKS • $•$ •

IX. INSTITUTE NOTES $\cdot .+\cdot \cdot \cdot \cdot \cdot \cdot \cdot \cdot \cdot 3^{81}$

\section{THE BRITISH INSTITUTE OF PHILOSOPHY}

THE Institute has no endowments, and its work, which includes Lecture Courses and Study Circles in the various Centres as well as the conduct of the Journal, is carried out on the most economical lines, but it cannot be expected that a liberal service be provided entirely from revenue derived from subscriptions at $£ \mathrm{I}$ Is. per annum.

Donatrons, of any amount, for the current year will be greatly appreciated by the Council.

All sympathizers with the Institute's work are invited to become members.

$\mathbf{R}$ 
PRINTED IN GREAT BRITAIN

BY UNWIN BROTHERS LIMITED

LON DON AND WOKING 